DOI: 10.23860/JMLE-2019-11-2-8

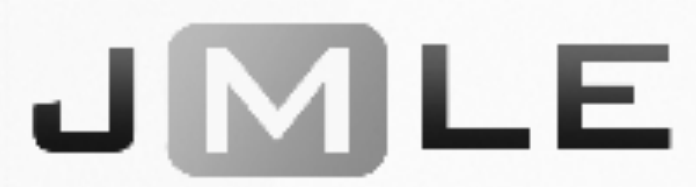

The National Association for Media Literacy Education's

Journal of Media Literacy Education 11 (2), 146 - 166

\title{
"So, Tell Me What Kind of a Thing It Really Is"-Finnish Older Adults Making Sense of Home Technology
}

\author{
Pilvikki Lantela \\ University of Lapland, Finland
}

\begin{abstract}
This article brings forth the experiential knowledge and views of sixteen Finnish older adults, (mean of age 84,9), who tried out home technology in their daily life, with the objective of discussing media literacy education in relation to this specific age group and context. The data were analyzed from the perspective of sensemaking as theorized by Karl Weick, which works as a heuristic enabling investigation of older adults' experiences in relation to home technology. The results show that the sensemaking of the participants is based on the identity of the non-user, retrospective reasoning and social context. For many, the technological solutions examined in this study did not seem to constitute a plausible answer to the perceived needs or realities of life. This study thus raises an important question: in the context of home technology implementation or media literacy, whose voice or sensemaking is heard? This general question comes with a set of related concerns and prompts further questions such as: Do older adults perceive a need for media literacy and how do they make sense of various media and the rapidly digitalizing culture? In media literacy education, older adults should be recognized within their unique life contexts.
\end{abstract}

Keywords: older adults, home technology, home care, sensemaking, media literacy education, critical gerontology

Sometimes portrayed as an economic burden, 'heavy users' of public services, and at other times as a powerful consumer force, the older generation has caught the attention of public and academic debates. Across EU, life expectancy at birth has risen by about ten years between 1960 and 2015 for both females and males. The overall percentage of people aged 70 and over is estimated to increase for the next 50 years (European Union, 2018). In Finland, the proportion of people aged 65 or over will rise from the present 19.9 per cent to 29 per cent by 2060 (Statistics Finland, 2018a). Within EU the share of people aged 80 and over (13\%) will be almost as large as the share of the young population aged $0-14(15 \%)$ by 2070 (European Union, 2018). The rising proportion of older people changes societies and communities and makes it necessary to take into account this population. 
These demographics are related to the question of care and public services. The politics of care are being renegotiated as the demographic dependency ratio (the number of children and pensioners per 100 persons of working age) rises. ${ }^{1}$ These changes, in turn, are closely connected with the fast-paced digitalization of societies. Technologies that are brought home are a rapidly evolving business and, in many countries, Finland included, these kinds of technologies play a major role in government strategies promoting older adults' continued independent living at home. Technologies are seen as one answer to the burning question of how to provide care for the older population with minimal costs in a climate of decreasing resources. (Bentley, Powell, Orrell, \& Mountain, 2018; Greenhalgh, Procter, Wherton, Sugarhood, \& Shaw, 2012; Sosiaali- ja terveysministeriö, 2017.)

In this article, media literacy is discussed in the context of older adults and home technology. Various home technologies are means of communication or media content consumption. Some devices, such as alarms and tablets, make it possible to exchange information and to establish and maintain contact with others. In addition, there is a growing pool of programs and interactive groups that are available to, or produced specifically for, older adults to be accessed via home technology devices. Hence, home technologies are intertwined with media and communications.

There is no consensus on the definition of media literacy among academic scholars (Palsa \& Ruokamo, 2015). I refer to media literacy after Livingstone, Van Couvering and Thumim (2005) and Aufderheide (1993) as an ability to access, understand, analyze and produce media messages. In the context of evolving home technologies, questions of access to and understanding of media are crucial. If and when people are homebound, such as is the case with many older adults - especially the 'oldest old' (i.e. people aged 80 and over) - the need for access to and understanding of media or technologies becomes a key issue, because they might be a crucial way of connecting with the outside world.

From the perspective of media literacy education, later years in life are a unique part of the human lifespan. Generally, various cognitive and physical changes related to ageing affect learning processes and the capacity to retain data (González-Oñate, Fanjul-Peyró, \& Cabezuelo-Lorenzo, 2015; McCreadie, 2010). In addition, older generations have grown up in a pre-digital culture (see, e.g., Rasi $\&$ O'Neil, 2014). On the other hand, older adults are not a uniform group: life stage, education and social circumstances might affect the digital inclusion or exclusion of a person more than age per se (Helsper \& Reisdorf, 2016; McCreadie, 2010). The proportion of older adults using a computer or the internet has steadily grown (Anderson \& Perrin, 2017; Eurostat, n.d.). Nonetheless, a relatively larger proportion of older adults belongs to the 'non-users' of technology (Helsper \& Reisdorf, 2016; Reisdorf \& Groselj, 2017). In Finland, 40 per cent of people aged 75 to 89 have used the internet in the past three months and only 19 per cent report using it daily (Statistics Finland, 2018b). In 2013, nearly half of the same age group

\footnotetext{
${ }^{1}$ In Finland, for instance, the dependency ratio is estimated to be 76 by 2060 , in comparison to 60.1 which it was in 2017 (Statistics Finland, 2018a).
} 
did not view IT-skills as necessary (Stenberg et al., 2014). For these reasons, older adults should be addressed in media literacy practice and research, which has traditionally been more focused on children and adolescents (Hakkarainen \& Hyvönen, 2010; Mihailidis, Hobbs, McDougall, \& Berger, 2015; Bordac, 2014).

The present study is situated at the intersection of critical gerontology and media literacy education. It discusses media literacy of older adults in the context of home technology and home care. The study is based on a Finnish home technology trial, the objective of which was to investigate how technological solutions could lengthen the period of and improve the quality of independent living at home in later years of life and to consider how these could be applied to the implementation of home care services. The trial is described in detail on page 6 . The aim of the article is to bring forth the experiential knowledge and views of older adults, who tried out home technology in their daily life, in order to discuss media literacy education in relation to this specific age group and context.

\section{TECHNOLOGY AT HOME}

In this article, home technology refers to the specific solutions used in the Finnish trial, examined in the present study and, more widely, to a variety of technological solutions designed to enable or improve living at home or to manage risks related to independent living, also referred to as 'assistive technology' (Fischer, David, Crotty, Dierks, \& Safran, 2014), 'telecare' (Bentley, Powell, Orrell, \& Mountain, 2018), 'mHealth' (Spann \& Stewart, 2018) or, more widely, 'gerontechnology' (Delello \& McWhorter, 2015). When this kind of technology is used for communicating or exchanging information (e.g., real-time video communication, interactive health or rehabilitation apps or programs), it can be understood as digital media technology. Viewed from the perspective of digital media technology, home technology also involves the dimension of media literacy education - an area this article focuses on.

Many studies emphasize the positive outcomes of technology and thus strengthen the idea of home technology as a solution for care politics (Khosravi \& Ghapanchi, 2016). Technological solutions, such as iPads, apps or homemonitoring solutions, can reduce or alleviate social isolation and loneliness (Barbosa Neves, Franz, Judges, Beermann, \& Baecker, 2017; Chen \& Schulz, 2016), increase family communication (Bradford, Van Kasteren, Xhang, \& Karunanithi, 2018), help transcend social and spatial barriers (Winstead et al., 2013), lead to a greater connection to society (Delello \& McWhorter, 2015), help manage health issues or cope with symptoms (Bradford et al., 2018; Kerssens et al., 2015), reduce falls (Tchalla et al., 2012) and foster independent living and safety (Stokke, 2016).

However, other studies point towards the potential unintended or negative outcomes of assistive technologies. Although expected to enable more efficient care, assistive technology can dehumanize the users it is intended to serve by

causing stigma and embarrassment. Efforts intended to be rational can result in irrational outcomes (Pritchard \& Brittain, 2015). New technologies can marginalize 
groups that are already disadvantaged, such as older adults with low income, no access to technology and low social support (Fang et al., 2018). Instead of enhancing independence, technology might reduce perceived independence (Bentley et al., 2014) and, due to the perceived difficulties, have a detrimental effect on self-esteem (Wilson, 2018). Additionally, the feeling of surveillance might lead to altering one's natural and spontaneous behavior at home (Bradford et al., 2018).

Regarding older adults, identified barriers to adopting assistive technologies consist, for example, of privacy concerns (Alsulami \& Atkins, 2016), concerns over cost (Bentley et al., 2018), safety and trust (Lie, Lindsay, \& Brittain, 2015), functionality, difficulties of use and suitability for daily use (Yusif, Soar, \& HafeezBaig, 2016), lack of confidence (Cook et al., 2016), negative stigma and reduced independence associated with the equipment (Bentley et al., 2018). Acceptance of such technology, in turn, is argued to be connected with expected benefits, characteristics of older adults such as cultural background or desire to age in place (Peek et al., 2014, 2015), perceived need for or interest in technology, willingness to invest effort in using the device, positive influence of social networks (Peek et al., 2015), as well as perceived peace of mind provided by technology (Bentley et al., 2018).

Instead of examining home technology from the perspective of adoption or acceptance, or treating them in terms of barriers or benefits, I approach the issue within an interpretive or cultural studies paradigm, focusing on the experiences of the end-users. My aim is to enrich the discussions of the complex nature of social reality that is present when older adults are familiarizing themselves with or using home technology.

\section{MAKING SENSE OF TECHNOLOGY}

The viewpoint and needs of older adults have been acknowledged in several gerontechnology studies (Claes, Devriendt, Tournoy, \& Milisen, 2015; Alsulami \& Atkins, 2016; Bentley et al., 2018; González-Oñate et al., 2015; Ziefle, Röcker, \& Holzinger, 2011; Peek at al., 2015; Lie, Lindsay, \& Brittain, 2015). However, many of these studies are based on surveys or interviews of people who might not actually use home technology, but rather, the data reflect their attitudes towards and conceptions of the issue. Assessing needs in theory is different from investigating or evaluating an actual response to technology in a real-life context. Using different technologies is such a multifaceted phenomenon that pilot studies are necessary for collecting accurate and realistic knowledge from front-line users.

In this article, my objective is to bring forth the experiential viewpoints and voices of older adults. To this end, I have applied the sensemaking perspective, as theorized by Karl Weick (1995), to the analysis of the data, which works as a heuristic that enables investigation of older adults' experiences in relation to a home technology trial. The sensemaking perspective consists of seven interrelated properties that provide a framework for explaining how and why people make sense as they do. These properties show that sensemaking is driven by plausibility rather than accuracy, focused on extracted cues, enactive of the environment, social, 
ongoing and grounded in identity construction and retrospective reasoning. (Weick, 1995; Helms Mills, 2010.)

Weick coined the term sensemaking that refers to the process "by which people seek plausibly to understand ambiguous, equivocal or confusing issues or events" (Brown, Colville, \& Pye, 2015, p. 266). Originally Weick did empirical research on disasters such as the Tenerife Air Disaster (Weick, 1990) and the Mann Gulch Disaster (Weick, 1993) and, traditionally, sensemaking has thus been connected with disruptions in organizational life. The "disruptive ambiguity" of an event forces people to make sense (Weick, Sutcliffe, \& Obstfeld, 2005). In this study, sensemaking is connected with society-wide changes: digitalization and change in the public service sector. At the grassroots level, older adults are experiencing and making sense of these changes for example through the use of home technology. Home technology provides an interesting case for sensemaking, since technologies - representing the unfamiliar and the impersonal-are brought to the most private sphere and space of life: home. As an unfamiliar phenomenon, home technology disrupts the flow of experience, creating a situation in which the object of experience cannot be understood routinely (Tökkäri, 2012).

Sensemaking makes it possible to address the issue of technology in an interpretative, social-psychological fashion, philosophically leaning on the socialconstructivist view (Helms Mills, 2010). Sensemaking has been used to study various organizational events, such as organizational change (see, e.g., Kataria, Kreiner, Hollensbe, Sheep, \& Stambaugh, 2017; Thurlow \& Helms Mills, 2015), but it has not been applied to gerontological or media literacy studies, which makes it a novel perspective to the subject at hand. Sensemaking research can be a critical endeavor if the researchers acknowledge the broader societal context of the sensemaking and power relationships within. Sensemaking is not just an individual performance, but happens in relation to cultural norms, rules and discourses, whereby the identity of the sensemaker is always formed within a wider cultural context, in which some arguments, viewpoints and identities are privileged over others. If power and politics are acknowledged, sensemaking research holds the potential for social change. (Helms Mills, Thurlow, \& Mills, 2010; Thurlow, 2010; Carroll, Helms Mills, \& Mills, 2008.)

This study adds up to the existing literature by applying the sensemaking perspective and by bringing forth the experiential viewpoint of older adults. Capturing the experiences and voices of older adults is an ethical act in itself because it underlines the value and meaning of knowledge produced by this group of people. This kind of knowledge is also needed in practice in developing professional practices, in initiatives targeted at enhancing media literacy of older adults and in designing services for this target group. It is impossible to affect a certain age group without acknowledging their own perspective into the issue at hand.

The research questions are:

1) How do older adults make sense of home technology in the context of the trial?

2) What aspects or properties explain or 'rationalize' the identified sensemaking? 


\section{DATA GATHERING AND ANALYSIS}

The trial under investigation was part of the Finnish government's nationwide key project Improved home care for older persons and enhanced informal care in all age groups funded by the Finnish Ministry of Social Affairs and Health. ${ }^{2}$ The trial was carried out in Finnish Lapland in 2017-2018 with 20 municipalities involved, as part of a regional sub-project $A$ Well-functioning Home Care to Lapland, which focused on developing home care practices. Finnish Lapland is sparsely populated rural area characterized by long distances. Migration from north to south in search of better employment opportunities is common and equal distribution of public services is a challenge. Hence, developing home care and means of remote care is especially important in this context. The task of the University of Lapland was to produce knowledge related to the development initiatives.

Three companies offering home technology solutions were chosen as partners for the trial, each of which provided a home technology solution to be used by the participants during the trial. Seniortek provided a home monitoring solution called 'Smart Flower Stand' (hereafter SFS). SFS provides family members or formal care providers information on the whereabouts of the user and sends alerts to the designated person (a family member or a formal care provider) in case of disruption in the daily life (e.g., staying in bed all day, leaving the house and not coming back). Sävelsirkku —officially translated as Sound Vitamins-provided an audio-based method of rehabilitation and recreation. Arctic Connect (AC) provided tablets, called 'picture-phones', through which the older people were able to listen to or participate in rehabilitation programs, talk with other participants, use realtime video communication with their children, home care providers, third sector volunteers or a local health care center. This study has a particular focus on the use of tablets, since they were a means for using digital media technology in the form of real-time video communication and interactive rehabilitation programs and hence have the highest relevance to digital media literacy.

\section{Data Gathering}

The older adults taking part in the research were living in different parts of Lapland, independently at home, but received home care and possibly other services in order to manage daily life. Each had either a tablet or SFS for a specific duration during the trial. Some had access to Sound Vitamins via the tablet. The participants were found with the help of municipal care workers who, among their customers, first provided potential participants with information on the research project with the objective of identifying persons who would be eligible to participate in the trial and likely to benefit from it, and then asked if they would be interested in taking part in the research. If the older adults were willing to participate, their contact information was passed on to the researchers who

\footnotetext{
${ }^{2}$ https://stm.fi/en/improved-home-care-for-older-persons-and-enhanced-support-for-all-agedinformal-carers
} 
contacted them, explained the idea of the study and made sure that each participant had filled in an agreement form. The research permission from the municipality was included in their participation in the project. Because of the nature of the trial, a preliminary ethical review was not conducted. The research arrangement did not produce a stimulus that could have caused potential physical or mental harm for the participants. In order to respect the autonomy of the participants and to take into account the possibility of their changing health condition, the idea and purpose of the study was brought to discussion regularly throughout the interview process and the participants' willingness to continue to take part in the study was regularly reaffirmed in the course of the trial.

Altogether twenty older adults (mean age 84,9) were interviewed, but four interviews were omitted from the data set because the trial did not start, contact with the participant was lost or a health condition prevented full participation in the interview. The data consist of interviews with sixteen older adults, each of whom was interviewed 2 to 6 times during the trial. The interviews were conducted by researchers and students from the University of Lapland and the Lapland University of Applied Sciences. 24 interviews were organized face-to-face at the interviewees' homes, 23 via telephone and 4 via tablet. Altogether 51 interviews were conducted between 2017 and 2018. The length of the interviews varied from 10 minutes to 1,5 hours, depending on the situation and the course of the trial. Altogether, there are 1759 minutes of audio-recorded interview material. Originally, the plan was to interview each research participant before and during the trial. However, due to the delayed start of the trials in some municipalities, the first interviews with some participants took place only after the trial had started.

Nearly all of the interviewees had health conditions and were on regular medication. In addition, some participants were experiencing benign forgetfulness or early stages of memory loss. Diagnosed memory disorder or undiagnosed memory decline was not an obstacle to participation if the participant was able and willing to participate in the interviews. The basic information of the participants can be found in table 1. In order to protect the anonymity of the participants, their names have been changed. When quoting the participants, the interviewee's age is marked in brackets.

Table 1 Basic information. Participant names have been anonymized.

\begin{tabular}{|l|l|l|l|}
\hline Name (gender) & $\begin{array}{l}\text { Age } \\
\text { in the beginning } \\
\text { of the trial) }\end{array}$ & $\begin{array}{l}\text { Living alone/ } \\
\text { with someone }\end{array}$ & $\begin{array}{l}\text { The device in the } \\
\text { trial }\end{array}$ \\
\hline Olavi (male) & 76 & $\begin{array}{l}\text { Living with a } \\
\text { spouse }\end{array}$ & Tablet \\
\hline Annikki ( female) & 83 & Living alone & SFS \\
\hline Marjatta (female) & 89 & Living alone & Tablet \\
\hline Kalevi (male) & 71 & Living alone & Tablet \\
\hline Liisa (female) & 84 & $\begin{array}{l}\text { Living alone } \rightarrow \text { in } \\
\text { the end of the trial }\end{array}$ & SFS \\
\hline
\end{tabular}




\begin{tabular}{|l|l|l|l|}
\hline & & $\begin{array}{l}\text { was transferred to a } \\
\text { care facility }\end{array}$ & \\
\hline Kaarina (female) & 85 & Living alone & Tablet \\
\hline Anneli (female) & 86 & Living alone & SFS \\
\hline Maria (female) & 91 & $\begin{array}{l}\text { Living alone } \\
\rightarrow \text { Her son visits and } \\
\text { stays over frequently }\end{array}$ & Tablet \\
\hline Kyllikki (female) & 84 & Living alone & SFS \\
\hline Helena (female) & 89 & Living alone & Tablet \\
\hline Anja (female) & 85 & Living alone & Tablet \\
\hline Juhani (male) & 89 & Living alone & Tablet \\
\hline Antero (male) & 87 & $\begin{array}{l}\text { Living with a } \\
\text { spouse }\end{array}$ & Tablet \\
\hline Eila (female) & 85 & $\begin{array}{l}\text { Living with a } \\
\text { spouse }\end{array}$ & Tablet \\
\hline Matti (male) & 88 & Living alone & SFS \\
\hline Anna (female) & 88 & $\begin{array}{l}\text { Living with her } \\
\text { son }\end{array}$ & Tablet \\
\hline
\end{tabular}

\section{Preliminary Remarks: Making Sense of the Unintelligible}

The task of the researchers was to investigate the viewpoints and experiences of the older adults trying out home technology. During the interviews, the older adults were asked about living at home, daily routines, formal and informal care, technology and especially the experiences concerning the trial at hand. ${ }^{3}$ The gathered data was rich: many participants shared openly about their lives in general. The talk about technology provided much information about the progression of the trials: the benefits, obstacles and practical issues related to the devices and their use.

The data revealed promising prospects. At best, the technological solutions were a means of strengthening social capital or the overall well-being of the participants as well as a means of developing home care practices. However, despite the positive outcomes, many of the participants did not end up utilizing the technological solutions provided on a daily basis. Only the formal home care distance-visit became a daily routine.

In addition, the talk of the interviewees reflected the meanings given toor the unintelligibility of - new technologies. When reading the data during the initial stages of the analysis process, one important observation that was made was the lack of proper concepts.

\footnotetext{
${ }^{3}$ Few examples of the interview questions concerning the trial: What kind of expectations do you have towards the trial? How has it felt like to learn to use the device? How has the device worked? Has the use of the device changed your daily routines?
} 
Interviewer: Did you talk more about what the... about for what purpose the device is intended and what would its potential benefits be?

Annikki: Well, not really

Interviewer: Yes

Annikki: Except that I got the impression that if I go to the toilet at night, it will register all

Interviewer: $\mathrm{Ok}$

Annikki: So, tell me what kind of thing it really is.

Annikki's (83) experience reflects also the other respondents' thoughts, especially at the beginning of the trial. There is a sense of uncertainty and unfamiliarity. The 'rules' of the device are not clear yet and the device does not have a proper name: it is 'a thing', something that escapes definition. If reality is constructed through language, people need concepts and words for reality to come together. How to understand or to make sense without proper concepts?

This remark lead to a closer examination of the data from the sensemaking perspective, reflecting the process of grasping the somewhat unintelligible. Hence, instead of listing the benefits or barriers of use, this study aims to understand the individual and their meaning-making in context. The main interest of the analysis does not lie in the outcomes of the trial, but in the process that led to the observed outcomes. The data are being analyzed from other angles in other publications. ${ }^{4}$

\section{Data Analysis}

Initially, all the parts in which the participants commented on the trial or technology, were extracted from the data. Furthermore, the extracts were divided thematically. This body of data, in turn, was read through the lens of sensemaking and the seven interrelated properties: plausibility, extracted cues, enactive of the environment, social, ongoing, retrospective and identity construction (Weick, 1995; Helms Mills, 2010). After reading and re-reading the data, especially three of the properties emerged in the sensemaking of the older adults, who in the analysis are referred to as sensemakers. The sensemaking of the participants was strongly connected with identity construction, retrospective reasoning and social context. These, in turn, were related to the question of plausibility.

\section{RESULTS}

\section{Making Sense of the Sensemakers: Identity Construction}

\footnotetext{
${ }^{4}$ Outila, M., \& Lantela, P. (2019). Samanaikaisesti hauras ja resilientti - Kategoria-analyysi ikääntyneiden itseä koskevasta puheesta [Frail and resilient at the same time: Category-analysis on older adults' talk about themselves]. Gerontologia, 33(1), 19-36.
} 
The knowledge of who we are and where we come from affects how we make sense (Helms Mills et al., 2010). The interviewees identify themselves mainly as non-technical persons or 'non-users' of technology. Kalevi (71) defines himself as a traditional person, who gives high value to social encounters and interaction: "I would say that I am a traditional person, and I trust personal interaction more, or give more value to it." Most interviewees do not own a computer or a smartphone and quite a few declared not being interested in such things. However, there are few exceptions: two of the interviewees use a computer to pay their bills, but admit that otherwise, they are not fluent in using it. Using a computer is "a bit like a game of chance", as Anja (85) puts it. This comment and the data, in general, reflect nonconfidence and lack of skills in using technological devices such as a computer.

The identity of a 'non-user' and difficulties to learn are also related to old age in the talk of the interviewees. Maria (91), who quit the trial because she did not use the device reasons:

Well, I didn't learn it properly, because I must simply admit that maybe it is old age or something else that has caught up with my skills. (Interviewer: Yes.) Made them rusty.

Thus, old age justifies non-use or struggles with technology and, in many cases, represents difficulties to remember or grasp new things. However, this does not mean lack of curiosity towards new things or unwillingness to learn. Despite having her share of troubles with the device, Helena (89) says: "It is nice that, even when you're up in years, there is interest in learning new things."

In a vein similar to the study of Helms Mills and Weatherbee (2006) on Hurricane Juan and the response of the citizens of Halifax, the (non-user) identity that emerged in the present study, does not provide (older) people with the experiences that would help them in an unexpected situation.

Interviewer: So if you have a problem with it, you will make a phone call? Kalevi: That's right. Then I can't do anything with it [the device].

In case of an unexpected problem, such as 'a box on the screen', a software update, audio issues during phone calls, the participants were usually helpless and dependent on the help of others. Due to the lack of familiarity with technology, they did not have daily scripts for using technological devices or a proper understanding of the logic of the digital environment. When I asked one of the participants why he had been in touch with his child with a basic cell phone instead of the tablet given to him for the purposes of the trial, he used a gesture to show how he automatically reaches for the cell phone when the idea of calling comes to his mind. Changing one's behavior is a complex process intertwined with one's identity. Letting go of the familiar scripts might present a threat to one's sense of self.

Anneli (86) quit the SFS trial due to false alarms, which bothered her children who kept receiving them. She was offered the tablet for the purposes of the trial, but she refused fervently. In discussing with her, she stated "[b]ecause I don't get it at all, I haven't even seen [it] (..) I don't want anything like that. I can 
use the regular phone to make calls. That's the whole point." This account reveals, interestingly, the intersection of the identity of the sensemaker and the retrospective reasoning in the art of sensemaking. Leaning on her identity as someone who does not understand technology ('I don't get it at all') and on her past experiences and daily scripts ('I can use the regular phone to make calls'), she reasons that she does not need any new devices. Listening to Anneli, one wonders if refusal could also be a form of resistance. It might be a way to hold on to a familiar identity or continuity of the self in the midst of changes that have come - and keep coming with ageing, or, an expression of will to hold on to the power one still has to make decisions over one's life.

\section{Past Experiences Count: Retrospective Reasoning}

Sensemaking is about answering the question "what's the story here?" and the answer is always in some sense retrospective (Weick et al., 2005, p. 410). Retrospection means that drawing conclusions when making sense of an event is based on earlier observations. A person notices something and gives it meaning based on previous experience and information derived from it. The explanation in the mind of the sensemaker is created "by looking back over earlier observations and seeing a pattern" (Weick et al., 2005, p. 412).

In quite a few cases, the older adults seemed to find the device hard to use or-despite positive expectations - the rate of use remained low. Kalevi (71) makes sense of the tablet by referring to his earlier experiences with technology. $\mathrm{He}$ explains that, despite participating in several computer courses earlier, he has not learned to use a computer. Now, difficulties he faces in using the device during the trial reaffirm the hunch based on his past experience and make him focus on cues that reinforce the idea of technology as complicated and difficult to learn (Weick et al., 2005).

Anja (85), who, at the beginning of the trial, was curious about the programs available through the tablet, explained later that she hadn't really been watching or listening to them since the programs do not fit into her daily schedule. This explanation seems rather odd because, over the course of the interview, it becomes clear that she has plenty of time to watch television and listen to the radio, being particularly keen on the latter activity because of the interesting content of the broadcasts. It seems that the question is not really about time or schedule, but about familiar scripts: Anja is used to certain behavior and her familiar way of life.

For Olavi (76), the tablet was a means of contacting the local health center in case of his wife's health problems. For Maria (91), too, the tablet was given as a means of contacting the local health center, because of her heart problems and earlier hospital visits. Olavi and Maria comment on the use of the devices:

Interviewer: So it has helped a bit, but not quite answered the need that you have?

Olavi: No it hasn't, not in our case. The panic attacks are such that the thing has no effect on them. 
Maria: if I have an emergency, it is the ambulance that gives me safety and not, no, yes I understand that it was meant to be used to give me advice when there are bad times, when there are difficult times, yes, and because I don't have control over that machine, then it is not really, well, I came to the conclusion that it is not so useful for me.

For Maria, the tablet is not a plausible solution for the experienced need. It takes too much time to remember how to use it each time and hence it is of no help in an emergency, which Maria has experienced several times. Maria's comment "I don't have control over that machine" also shows the lack of self-competence and mastery over the device. Her sensemaking can be interpreted as related to her earlier life experiences. Computers came to her workplace only after she had retired and she has always enjoyed being outdoors, so she has never had a need to familiarize herself with new technology. Thus, the idea of having a device such as the tablet as part of her life now is alien to her.

Olavi perceives the procedure of contacting the health center via the tablet as being of no use in case of the panic attacks experienced by his wife. The retrospective nature of sensemaking becomes evident in his comment on the interviewer's note on how hard it is to live and cope with illnesses: "[t]hat is not how it goes, we can't have machines taking control over these things just like that." Machines represent something new and unfamiliar to Olavi. The difficulties caused by illnesses are challenging in themselves, and handling an intimidating situation with the help of an unfamiliar device causes even more stress. Weick (1990) argues that pressure leads people to retreat to familiar scripts - what they learned first. Retrospective reasoning and acting accordingly might thus be intensified in a situation that causes pressure, such as coping with ill health. For both Maria and Olavi, the device does not improve their lived experience with illness (Greenhalgh et al., 2013).

\section{Social Factors Influencing Sensemaking}

Overall, the sensemakers should be seen in their wider sociocultural context encompassing past, present and future. The formative context in which the participants grew up and completed their life's work was a rural society, where skills of physical and practical nature were needed and valued. Technological skills were not an asset during the participants' working years, and computers became more common only after most of the participants had already retired. Against this background, there seems to be an incongruity between the mindset of the interviewees and the present-day understanding of the significance of digital competences - similar to that revealed in Rasi and Kilpeläinen's (2015) study which found that meanings older people assigned to digital competencies were "often subordinate to other, more meaningful previous, present or future activities and competences" (p. 158).

Also, the current social surroundings affect sensemaking (Weick, 1995). As was discussed above, Anja (85) explained that watching the programs did not fit into her daily schedule. Another explanation she gave for the low rate of use of the device was that she believed the device to be defective. 
Anja: I'm telling you, it is that device that is, that has been defect-, defective all along.

Interviewer: I see.

Anja: So often it does not show the programs at all.

Interviewer: $\mathrm{Oh}$.

Anja: Not even a single evensong, and

Interviewer: Oh, how is it then, the programs are just not available there, or?

Anja: Yes, so it is.

On another occasion, she admits that she might be having some difficulties herself in using the device, but this storyline is not a strong one compared to the two abovementioned reasons she keeps repeating multiple times. One reason for this might be the social context of the interviews. Anja is a widow and lives alone. Her children live in southern Finland and abroad. As she has noticed herself, her memory is deteriorating and she has started to need help with some chores at home. Nevertheless, she is very keen on living at home for the rest of her life. Against this background, and maybe with a worried mind, Anja seems to be under a pressure to convince others - in this case, the interviewer - of her competence of living at home. In this context, she might consider it safer to express her sensemaking in a way that does not weaken her position as a competent, capable-of-living-at-home person.

Also, the sensemaking of Helena (89) can be interpreted in the context of her wider social network. Although learning has been rather difficult for her, Helena is very positive about the trial and repeatedly refers to her good memory and condition as a nearly 90 -year-old person. Her sharp memory and other abilities make her stand out from among the other older adults in the village.

I'm pretty much an old person already [laughter]. That's why they suggested me from here [as someone who could participate] because with many people, their memory ain't working, or anything else for that matter, so... so, that's why they say that here [I am] the only person who would be suitable for this.

Helena acknowledges that, in her village, she is one of the few older people with a well-functioning memory. Being suitable and chosen for the trial puts her in a special position of a 'change-agent', strengthens her positive self-image and her idea of herself as a capable person. Maybe another aspect that fosters her positive uptake on the trial is the fact that she has been able to make sense of the device with others. Unlike many other participants, she has had the opportunity to contact her son or a local home care worker who is specialized in home technology. Many other participants were left to make sense of the device and its use mainly on their own. The sensemaking of the participants might have looked different if they had had the possibility to make sense together with others, peers or other social contacts (see, e.g., Delello \& McWhorter, 2015). 
Another important notion related to the social context in which sense is made is the older adults' somewhat vulnerable position as people with deteriorating health and, in many cases, deteriorating memory. For example, Helena (89), who was initially active in learning to use the device, had to quit the trial after her health deteriorated. "I couldn't manage it any longer. I've been in such a bad condition that I had to give it up." The vulnerability affects sensemaking. One has to have enough strength in order to make sense.

\section{DISCUSSION}

Based on the results, sensemaking the older adults examined in this study engaged in was rooted in their social context, retrospective reasoning based on earlier experiences and identity of a non-technical person or a 'non-user'. The study revealed that, for many, the technological solutions did not seem like a plausible answer to the perceived needs and realities of life. Many of the older adults viewed the trial in a positive and polite manner, at least in the beginning, but their attitude did not make a difference if the use of the devices in the daily life did not seem plausible in the long run. The data suggest that, for example, familiarizing oneself with the technology already prior to the onset of serious health issues or having stronger social support networks - the importance of which has been identified in earlier studies as well (Barbosa Neves et al., 2017) — could have contributed to a different, more positive kind of sensemaking. In line with earlier studies, the results of the study show that implementing technology in everyday lives of older adults or digitalizing care services is not a straightforward procedure. Instead, it is intertwined with the complex social realities of end-users (Stokke et al., 2016; Hedman, Lindqvist, \& Nygård, 2016; Bradford et al., 2018).

According to this study, many Finnish older adults living in Lapland are not familiar with new technologies or media. They trust and value live social interaction and relationships. Their identity is rooted in the rich life experience, which stands in contradiction to the new digital world and the identities it represents. In the light of the data, it seems as if many of the older adults were saying: "the digital environment and citizenship is not who we are." The use of home care technologies disrupts the flow of routine experience, challenges routine behavior and the continuity of the self. This continuity is also challenged by everyday life, colored with unstable health, possible memory problems, difficulty in moving around or taking care of the daily chores.

In addition, there are concerns about the possibilities of living at home and, on the other hand, about getting enough help and support in daily life. The everyday life is also framed with national and local political decisions, social networks and economic possibilities. Thus, sensemaking, or the use or rejection of technologies, is not an individual endeavor, nor a matter of attitude or skills - even though these may play a part - but intertwined with much deeper and wider social, structural and political issues (Helsper \& Reisdorf, 2016; Smith, 2014). This kind of holistic point of view, which seeks to address the complexity of the reasons why something constitutes an incentive or a barrier to using technology, is lacking in much of the 
existing barrier or acceptance research (e.g., Alsulami \& Atkins, 2016; Peek et al., 2014; Yusif et al., 2016).

All this poses a challenge to media literacy education initiatives aimed towards older population and emphasizes the careful contextualizing of media literacy efforts. The results also show that media literacy initiatives targeted at older adults should focus on access to technologies and the understanding of the digital environment. Producing media content is a far cry from the realities of many older adults, for whom the purpose and meaning of various media or technologies are not clear or who have no self-confidence to use the devices in their daily life.

It has been suggested that the digitalization of an individual is necessary for active participation in society (Hobbs, 2010). The results of this study point to another direction. For these Lappish older adults, digitalization did not equal active citizenship. On the contrary, despite their limitations or incapacity to leave home altogether, the participants found their ways to be involved in the community, if they deemed it as important for themselves. Scant or non-use of technologies did not mean social exclusion or non-participation communally or politically. Hence, there seems to be a discrepancy of the idea of an active citizen between the societal and political representatives and older adults. If digitalization or media literacy is something that is forced upon the older people in a top-down manner, the initiatives to educate and involve the older generations will most likely fail. Media literacy education efforts targeted at the older population should start by recognizing the existing forms of participation and media in use and ground the work in something that is already meaningful to older people - recognize older adults in their context (Rasi \& O'Neil, 2014). It is vital to discuss and ponder with older adults themselves what kinds of possibilities various digital media could offer to enlarge their scope of involvement. However, access to or the use of media should not become a normative expectation that defines a decent or active citizen.

Sensemaking is about forming a plausible storyline. This leads us to an important question: when it comes to home technology or media literacy, whose voice or storyline gets heard? Whose identity or plausibility matters? In political discussions, the sensemaking of older adults or their loved ones is not much heard. Rather it is the sensemaking of the politicians and entrepreneurs that dominates the societal discussion and decision making. In managerial practices, it is sometimes assumed that the accuracy of the manager's perception determines the success of the desired outcome. According to the sensemaking perspective, it is not the accuracy, but the plausibility that matters, and not only the plausibility of leaders but plausibility in the minds of the workers or front-line users. (Weick et al., 2005.) This is why it is crucial to find out whether older adults perceive technological devices or apps useful and plausible in their daily life and circumstances. And in the context of media literacy education, it is necessary to ask if older adults perceive a need for media literacy and how they make sense of various media and the rapidly digitalizing culture. Co-operation of various stakeholders and taking the viewpoints of diverse groups into account is pivotal in societal change processes, such as promoting technological solutions in eldercare or enhancing the media literacy of older generations (Kernisan, 2016). 
This study has its limitations. The research was conducted in Finnish Lapland and thus the results might not reflect the realities of other contexts. In addition, the number of participants was fairly low due to the various recruitment challenges - among them declining health within the target age group. The mean age $(84,9)$ of the participants was rather high and all lived in small cities or villages. It is also necessary to bear in mind that, since the participants were recruited with the help of home care workers, the older adults with a good state of health who do not need home care services were not in the scope of this research. Regarding the analysis, it is important to acknowledge sensemaking at two levels. The analysis focuses on the sensemaking of the participants, but another sensemaking process goes on in the mind of the researcher, surely not without a bias. Having conducted part of the interviews myself helped in forming a richer picture of the participants, and throughout the analysis process, I aimed to critically reflect on my own sensemaking, in order to do justice to the data gathered. Sensemaking is connected especially with the disruptions in the stream of experiences. According to this line of thought, if technologies work in an optimal manner, they might not be made sense of, since there are no interruptions, nothing that requires sensemaking. For this reason, sensemaking might be more suitable for analyzing the experiences of unintelligibility or difficulties - in the analysis the more positive aspects might be hidden from the gaze of the researcher.

\section{Conclusion}

In a fast-paced and changing society, hearing the voice of older adults is an ethical question. Gathering information from older participants themselves is an ethical act because it means that the knowledge they hold has value in itself. The sensemaking of older adults should be taken into account and heard in public discussions and debates, whether the topic is digitalization of services or media literacy education of older generations.

Also, based on the results, older adults are a somewhat vulnerable group regarding digital know-how and media literacy. Changes in physical or cognitive condition might drain a person's energy, constituting an obstacle to orienting to new, unfamiliar things that require extra effort mentally. This is not to say that changes or learning new things would not be possible, but the social reality of older people is distinctively different from that of many other age groups. At the same time, it is pivotal to keep in mind that older adults, in Finland or globally, are not a uniform group, but a heterogeneous one.

\section{Acknowledgements}

I would like to thank professor Merja Laitinen (University of Lapland, Rovaniemi) and professor Jean Helms Mills (University of Saint Mary's, Halifax) and the two anonymous reviewers for useful comments and suggestions on earlier versions of the manuscript. The research was funded by the Finnish Ministry of Social Affairs and Health (Project: Toimiva Kotihoito Lappiinmonimuotoiset tuen muodot kotona asumiseen, 2016-2018). 


\section{REFERENCES}

Alsulami, M. H., \& Atkins, A. S. (2016). Factors influencing ageing population for adopting ambient assisted living technologies in the Kingdom of Saudi Arabia. Ageing International, 41(3), 227-239.

Anderson, M., \& Perrin, A. (2017). Tech adoption climbs among older adults. Report. Pew Research Center. Retrieved from http://www.pewinternet.org/2017/05/17/technology-use-among-seniors/

Aufderheide, P. (1993). Media literacy. A Report of the National Leadership Conference on Media Literacy. Washington, DC: Aspen Institute.

Barbosa Neves, B., Franz, R., Judges, R., Beermann, C., \& Baecker, R. (2017). Can digital technology enhance social connectedness among older adults? A feasibility study. Journal of Applied Gerontology, 38(1), 49-72.

Bentley, C. L., Powell, L. A., Orrell, A., \& Mountain, G. A. (2014). Addressing design and suitability barriers to telecare use: Has anything changed? Technology and Disability, 26(4), 221-235.

Bentley, C. L., Powell, L. A., Orrell, A., \& Mountain, G. A. (2018). Making telecare desirable rather than a last resort. Ageing \& Society, 38(5), 1-28.

Bordac, S. (2014). Introduction to media literacy history. Journal of Media Literacy Education, 6(2), 1-2.

Bradford, D. K., Van Kasteren, Y., Zhang, Q., \& Karunanithi, M. (2018). Watching over me: Positive, negative and neutral perceptions of in-home monitoring held by independent-living older residents in an Australian pilot study. Ageing \& Society, 38(7), 1377-1398.

Brown, A. D., Colville, I., \& Pye, A. (2015). Making sense of sensemaking in organization studies. Organization Studies, 36(2), 265-277.

Carroll, W. R., Helms Mills, J., \& Mills, A. J. (2008). Managing identity and resistance: Making critical sense of call centre management. Gestion 2000, 25(6), 57-81.

Chen, Y. R. R., \& Schulz, P. J. (2016). The effect of information communication technology interventions on reducing social isolation in the elderly: A systematic review. Journal of Medical Internet Research, 18(1).

Claes, V., Devriendt, E., Tournoy, J., \& Milisen, K. (2015). Attitudes and perceptions of adults of 60 years and older towards in-home monitoring of the activities of daily living with contactless sensors: An explorative study. International Journal of Nursing Studies, 52(1), 134-148.

Cook, E. J., Randhawa, G., Sharp, C., Ali, N., Guppy, A., Barton, G., ... Crawford-White, J. (2016). Exploring the factors that influence the decision to adopt and engage with an integrated assistive telehealth and telecare service in Cambridgeshire, UK: A nested qualitative study of patient 'users' and 'non-users'. BMC Health Services Research, 16(137).

Delello, J. A., \& McWhorter, R. R. (2015). Reducing the digital divide: Connecting older adults to iPad technology. Journal of Applied Gerontology, 36(1), 3-28.

European Union. (2018). The 2018 ageing report. Underlying assumptions and projection methodologies. European economy institutional paper 065. 
Luxembourg: European Union. Retrieved from

https://ec.europa.eu/info/sites/info/files/economy-finance/ip065 en.pdf

Eurostat. (n.d.). People in the EU-Statistics on an ageing society. Retrieved from

https://ec.europa.eu/eurostat/statistics-

explained/index.php?title=People in the EU -

statistics_on_an_ageing_society\#Senior_citizens_online_.E2.80.94_silve

r surfers

Fang, M. L., Siden, E., Korol, A., Demestihas, M. A., Sixsmith, J., \& Sixsmith, A. (2018). A scoping review exploration of the intended and unintended consequences of eHealth on older people: A health equity impact assessment. Human Technology, 14(3), 297-323.

Fischer, S. H., David, D., Crotty, B. H., Dierks, M., \& Safran, C. (2014). Acceptance and use of health information technology by communitydwelling elders. International Journal of Medical Informatics, 83(9), 624635.

González-Oñate, C., Fanjul-Peyró, C., \& Cabezuelo-Lorenzo, F. (2015). Use, consumption and knowledge of new technologies by elderly people in France, United Kingdom and Spain. Comunicar, 23(45), 19-28.

Greenhalgh, T., Procter, R., Wherton, J., Sugarhood, P., \& Shaw, S. (2012). The organising vision for telehealth and telecare: Discourse analysis. $B M J$ Open, 2012(2).

Greenhalgh, T., Wherton, J., Sugarhood, P., Hinder, S., Procter, R., \& Stones, R. (2013). What matters to older people with assisted living needs? A phenomenological analysis of the use and non-use of telehealth and telecare. Social Science \& Medicine, 93, 86-94.

Hakkarainen, P., \& Hyvönen, P. (2010). Tietokoneeton elämä yli 60-vuotiaan valintana. [Over 60-year-old person's deliberate choice of a computerless life: Emotions and justifications]. Media \& Viestintä, 33(4), 79-96.

Hedman, A., Lindqvist, E., \& Nygård, L. (2016). How older adults with mild cognitive impairment relate to technology as part of present and future everyday life: a qualitative study. BMC Geriatrics, 16(73).

Helms Mills, J., Thurlow, A., \& Mills, A. J. (2010). Making sense of sensemaking: The critical sensemaking approach. Qualitative Research in Organizations and Management: An International Journal, 5(2), 182-195.

Helms Mills, J. (2010). Sensemaking. In A. J. Mills, G. Durepos \& E. Weibe (Eds.), Encyclopedia of case study research (pp. 852-855). Thousand Oaks, CA: Sage.

Helms Mills, J., \& Weatherbee, T. G. (2006). Hurricanes hardly happen: Sensemaking as a framework for understanding organizational disasters. Culture and Organization, 12(3), 265-279.

Helsper, E. J., \& Reisdorf, B. C. (2016). The emergence of a 'digital underclass' in Great Britain and Sweden: Changing reasons for digital exclusion. New Media \& Society, 19(8), 1253-1270.

Hobbs, R. (2010). Digital and media literacy: A plan of action. A white paper on the digital and media literacy recommendations of the Knight Commission on the information needs of communities in a democracy. Washington: 
Aspen Institute. Retrieved from

https://files.eric.ed.gov/fulltext/ED523244.pdf

Kataria, N., Kreiner, G., Hollensbe, E., Sheep, M. L., \& Stambaugh, J. (2017).

The catalytic role of emotions in sensemaking: Evidence from the blogosphere. Australian Journal of Management, 43(3), 456-475.

Kernisan, L. (2016). Promises and pitfalls: Technology and the future of delivering eldercare. Generations, 40(1), 92-98.

Kerssens, C., Kumar, R., Adams, A. E., Knott, C. C., Matalenas, L., Sanford, J. A., \& Rogers, W. A. (2015). Personalized technology to support older adults with and without cognitive impairment living at home. American Journal of Alzheimer's Disease \& Other Dementias ${ }^{\circledR}, 30(1), 85-97$.

Khosravi, P., \& Ghapanchi, A. H. (2016). Investigating the effectiveness of technologies applied to assist seniors: A systematic literature review. International Journal of Medical Informatics, 85(1), 17-26.

Lie, M. L., Lindsay, S., \& Brittain, K. (2015). Technology and trust: Older people's perspectives of a home monitoring system. Ageing \& Society, 36(7), 1501-1525.

Livingstone, S., Van Couvering, E., \& Thumim, N. (2005). Adult media literacy: A review of the research literature on behalf of Ofcom. London:

Department of Media and Communications, London School of Economics and Political Science. Retrieved from http://core.ac.uk/download/pdf/4155054.pdf

McCreadie, C. (2010). Technology and older People. In D. Dannefer \& C. Phillipson (Eds.), The SAGE handbook of social gerontology (pp. 607617). London: Sage.

Mihailidis, P., Hobbs, R., McDougall, J., \& Berger, R. (2015). Building a global community for media education research. Journal of Media Literacy Education, 7(1), 1-3.

Palsa, L., \& Ruokamo, H. (2015). Behind the concepts of multiliteracies and media literacy in the renewed Finnish core curriculum: A systematic literature review of peer-reviewed research. Seminar.net-International Journal of Media, Technology \& Lifelong Learning, 11(2). Retrieved from https://journals.hioa.no/index.php/seminar/article/view/2354

Peek, S. T., Luijkx, K. G., Rijnaard, M. D., Nieboer, M. E., van der Voort, C. S., Aarts, S., ... Wouters, E. J. (2015). Older adults' reasons for using technology while aging in place. Gerontology, 62(2), 226-237.

Peek, S. T., Wouters, E. J., van Hoof, J., Luijkx, K. G., Boeije, H. R., \& Vrijhoef, H. J. (2014). Factors influencing acceptance of technology for aging in place: A systematic review. International Journal of Medical Informatics, 83(4), 235-248.

Pritchard, G. W., \& Brittain, K. (2015). Alarm pendants and the technological shaping of older people's care: Between (intentional) help and (irrational) nuisance. Technological Forecasting and Social Change, 93, 124-132.

Rasi, P., \& Kilpeläinen, A. (2015). The digital competences and agency of older people living in rural villages in Finnish Lapland. Seminar.netInternational Journal of Media, Technology \& Lifelong Learning, 11(2). 
Retrieved from

https://journals.hioa.no/index.php/seminar/article/view/2357

Rasi, P., \& O'Neil, C. (2014). Dinosaurs and fossils living without dangerous tools: Social representations of computers and the Internet by elderly Finnish and American non-users. Seminar.net-International Journal of Media, Technology \& Lifelong Learning, 10(1). Retrieved from https://journals.hioa.no/index.php/seminar/article/view/2378

Reisdorf, B. C., \& Groselj, D. (2017). Internet (non-) use types and motivational access: Implications for digital inequalities research. New Media \& Society, 19(8), 1157-1176.

Smith, A. (2014). Older adults and technology use. Pew Research Center. Retrieved from http://www.pewinternet.org/2014/04/03/older-adults-andtechnology-use/

Sosiaali- ja terveysministeriö. (2017). Laatusuositus hyvän ikääntymisen turvaamiseksi ja palvelujen parantamiseksi 2017-2019. Sosiaali- ja terveysministeriön julkaisuja 2017:6. [Quality recommendation to guarantee good ageing and improved services; publication of the Finnish Ministry of Social Affairs and Health] Helsinki, Finland: Sosiaali- ja terveysministeriö.

Spann, A., \& Stewart, E. (2018). Barriers and facilitators of older people's mHealth usage: A qualitative review of older people's views. Human Technology, 14(3), 264-296.

Statistics Finland. (2018a). Population structure. Retrieved from http://www.stat.fi/til/vaerak/index en.html

Statistics Finland. (2018b). Survey on use of information and communications technology. Retrieved from http://www.stat.fi/til/sutivi/2018/sutivi_2018_2018-1204_tie_001_en.html

Stenberg, L., Nordlund, M., Alastalo, K., Forsberg, K., Intosalmi, H., Nykänen, J., ... Virkkunen, A. (2014). Näkemyksiä ikäteknologiasta - KÄKÄTE-kyselyt yksissä kansissa. Käkäte raportteja 6/2014 [Views of gerontechnology. Käkäte-project reports 6/2014)] Vanhus- ja lähimmäispalvelun liitto ja Vanhustyön keskusliitto. Retrieved from https://www.valli.fi/fileadmin/user_upload/Julkaisut_pdf/Raportit_pdf/ KAKATE_Kyselyt_kooste.pdf

Stokke, R. (2016). The personal emergency response system as a technology innovation in primary health care services: An integrative review. Journal of Medical Internet Research, 18(7). Retrieved from https://www.ncbi.nlm.nih.gov/pmc/articles/PMC4965612/

Tchalla, A. E., Lachal, F., Cardinaud, N., Saulnier, I., Bhalla, D., Roquejoffre, A., ... Dantoine, T. (2012). Efficacy of simple home-based technologies combined with a monitoring assistive center in decreasing falls in a frail elderly population (results of the Esoppe study). Archives of Gerontology and Geriatrics, 55(3), 683-689. 
Thurlow, A., \& Helms Mills, J. (2015). Telling tales out of school: Sensemaking and narratives of legitimacy in an organizational change process. Scandinavian Journal of Management, 31(2), 246-254.

Thurlow, A. (2010). Critical sensemaking. In A. J. Mills, G. Durepos \& E. Wiebe (Eds.), Encyclopedia of case study research (pp. 257-260). Thousand Oaks, CA: Sage.

Tökkäri, V. (2012). Käsittämätöntä. Mielekkyyden luomisen keinot ja funktiot työyhteisön kertomuksissa [Confronting the incomprehensible: The means and functions of sensemaking in stories of members of an organization] Rovaniemi, Finland: Lapin yliopistokustannus.

Weick, K. E., Sutcliffe, K. M., \& Obstfeld, D. (2005). Organizing and the process of sensemaking. Organization Science, 16(4), 409-421.

Weick, K. E. (1995). Sensemaking in organizations. London: Sage.

Weick, K. E. (1993). The collapse of sensemaking in organizations: The Mann Gulch disaster. Administrative Science Quarterly, 38(4), 628-652.

Weick, K. E. (1990). The vulnerable system: An analysis of the Tenerife air disaster. Journal of Management, 16(3), 571-593.

Wilson, C. (2018). Is it love or loneliness? Exploring the impact of everyday digital technology use on the wellbeing of older adults. Ageing \& Society, 38(7), 1307-1331.

Winstead, V., Anderson, W. A., Yost, E. A., Cotten, S. R., Warr, A., \& Berkowsky, R. W. (2013). You can teach an old dog new tricks: A qualitative analysis of how residents of senior living communities may use the web to overcome spatial and social barriers. Journal of Applied Gerontology, 32(5), 540-560.

Yusif, S., Soar, J., \& Hafeez-Baig, A. (2016). Older people, assistive technologies, and the barriers to adoption: A systematic review. International Journal of Medical Informatics, 94, 112-116.

Ziefle, M., Röcker, C., \& Holzinger, A. (2011). Medical technology in smart homes: Exploring the user's perspective on privacy, intimacy and trust. In 2011 35th IEEE Annual Computer Software and Applications Conference Workshops (pp. 410-415). IEEE. Retrieved from https://ieeexplore.ieee.org/document/6032273 